\title{
Gastrointestinal Trichocephalosis Associated With Candidiasis in a Pig
}

\author{
Flore CHIRILA $\breve{~}^{1}$, Nicodim FIȚ ${ }^{1}$, George NADĂ $S^{1}$, Sorin RĂPUNTEAN ${ }^{1}$, Marian TAULESCU ${ }^{1}$, Cosmina \\ BOUARI $^{1}$, Octavian NEGREA ${ }^{1}$, Zamfir MARCHIŞ ${ }^{1}$ \\ ${ }^{1}$ University of Agricultural Sciences and Veterinary Medicine, Faculty of Veterinary Medicine \\ Mănăştur Street, 400372, Cluj-Napoca, Romania, \\ *Corresponding author e-mail: flore.chirila@usamvcluj.ro
}

Bulletin UASVM Veterinary Medicine 71(2) / 2014,

Print ISSN 1843-5270; Electronic ISSN 1843-5378

DOI:10.15835/buasvmcn-vm: 10698

\begin{abstract}
The most common illnesses in animals caused by yeast of the genus Candida infections occur as mastitis after prolonged antibiotic treatment in the form of dermatitis in dogs and systemic candidiasis. In contrast, pigs infected with Candida albicans cases are rarely mentioned even in the international literature. Coprologic sample was collected in a sterile plastic faces collector, and was kept in a refrigerator until the next day for the laboratory examinations. Stool sample was collected after 24 hours of treatment with avermectins. On macroscopic examination we observed parasites calibrated unequal, with elongated shape while direct parasitological examination has revealed the presence of characteristic eggs, lemon shaped, budding ends aspect, undeveloped. Bacterioscopic examination of feces in a Gram stained smear revealed fungal elements represented by oval cells, some budding cells and pseudohiphae presence. Diagnosis of these diseases can be overlooked in cases of incomplete laboratory examination. The result of treatment in field under these circumstances is ineffective because it is incomplete.
\end{abstract}

Keywords: Candida albicans, gastrointestinal disorders, piglets, Trichocephalus spp.

\section{INTRODUCTION}

Yeasts have the natural habitat human, animal skin and mucous membranes (4). From this level under certain conditions contribute to decreased body resistance; they can reach various organs and mucous membranes causing serious illness, sometimes fatal $(9,5)$.

The most common illnesses in animals caused by yeast of the genus Candida infections occur as mastitis after prolonged antibiotic treatment (3) in the form of dermatitis in dogs and systemic candidiasis $(1,6)$.

In contrast, pigs infected with Candida albicans cases are rarely mentioned even in the international literature $(8,2)$.

\section{MATERIALS AND METHODS}

Coprologic sample was collected in a sterile plastic faces collector, and was kept in a refrigerator until the next day for the laboratory examinations. They were represented by direct parasitological examination, bacterioscopic exam in Gram stained smear and confirmation by mycological examination (cultivation in glucose broth and glucose agar).

\section{RESULTS AND DISCUSSION}

Stool sample was collected after 24 hours of treatment with avermectins. On macroscopic examination we observed parasites calibrated unequal, with elongated shape while direct parasitological examination has revealed the presence of characteristic eggs, lemon shaped, budding ends aspect, undeveloped (Fig. 1).

Bacterioscopic examination of feces in a Gram stained smear revealed fungal elements represented by oval cells, some budding cells and pseudohiphae presence.

Geohelminths by their pathogenetic mechanism: mechanical irritant, toxic, and immuno- 


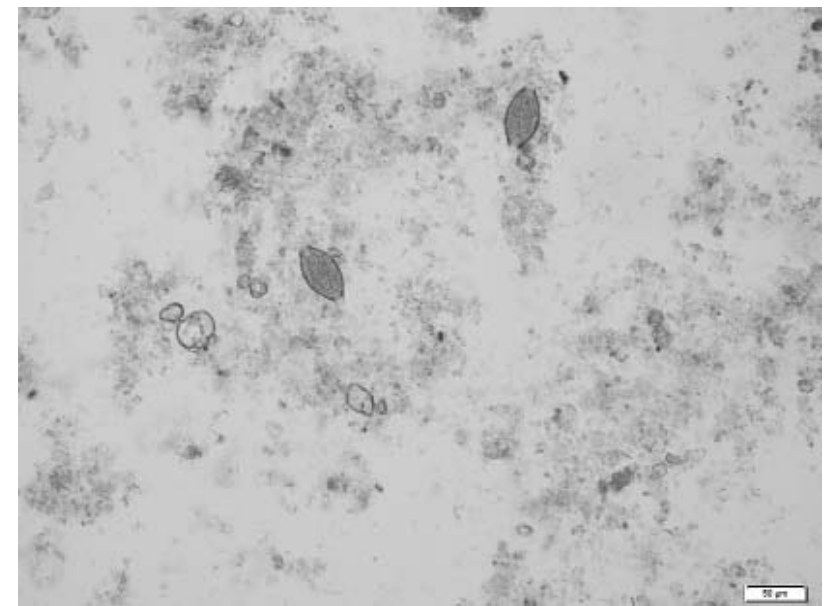

Fig.1. Direct parasitologic examination Trichocephalus spp. eggs- 200x

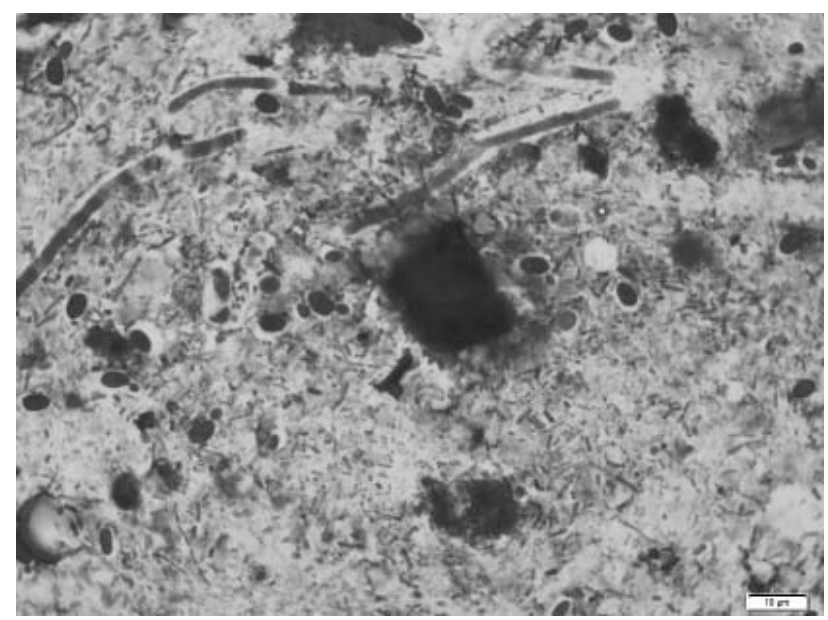

Fig. 2. Yeast cells, some of them budded, and pseudohiphae in faeces - 1000x

suppressive action, favor bacteria, viruses or fungi penetration in the body (7), as demonstrated in this case. As a contributing factor, may be considered also feeding the animal of dairy products, especially milk and sour whey. Strain of Candida spp., isolated within this study, presents typical morphology including pseudohipheae allows us to conclude that the specie is $C$. albicans, which is only capable of producing such pseudohiphae and their presence confirms its pathogenicity. Digestive infections with fungi group make us consider that their incidence in pigs could be much higher as it is known today, many cases escaping diagnosis due to incomplete laboratory examination or that not all animal bodies are sent to the lab. An argument in this direction is also our earlier observations on the microbial porting pharyngeal tonsils in pigs (2).

\section{CONCLUSIONS}

In pigs are revealed associated illnesses (fungi plus parasites).

Diagnosis of these diseases can be overlooked in cases of incomplete laboratory examination.

The result of treatment in field under these circumstances is ineffective because it is incomplete.

\section{REFERENCES}

1. Brown RM, Thompson CA, Mohamed FM (2005) Systemic candidiasis in an apparently immunocompetent dog, J. Vet Diagn Invest 17:272-276.

2. Dragomir D, Mihaiu M, Chirilă F, Rotaru 0; Microbial colonisation of swine adenoids (pharynegeal tonsils) target control for meat safety Lucrări ştiințifice medicină veterinară Timişoara 2012, vol. XLV (2), 115.

3. Hanzen Ch. (2009-2010) la pathologieinfectieuse de la glande mammaire. Etiopathogénie et traitements, Approche individuelle et de troupeau

4. www.therioruminant.ulg.ac.be/notes/200910/R22

5. Markey B, Archambault FLM, Cullinane A, Maguire D Clinical Veterinary microbiology, Second Edition 2013, Printed in China p. 487.

6. Raz-Pasteur A, Ullmann Y, Berdicevsky I (2011).The Pathogenesis of Candida Infections in a Human Skin Model: Scanning Electron Microscope Observations, ISRN Dermatology, Article ID 150642, 6 pages

7. Skoric M, Fictum P, Slana I, Kriz P, Pavlik P (2011) A case of systemic mycosis in a Hovawart dog due to Candida albicans, Veterinarni Medicina 56(5): 260-264.

8. Şuteu I, Cozma V, Bolile Parazitare la animalele domestice, Editura Ceres 1998, p. 344

9. The Merck Veterinary manual, Eighth Edition 1998, p. 461-462

10. umvf.univ-nantes.fr/parasitologie/enseignement/ candidoses/site/html/cours.pdf. 